\title{
ALGAE-BASED HEAVY METAL REMEDIATION IN ACID MINE DRAINAGE: A REVIEW
}

\author{
MANG, K. C. - NTUSHELO, K.* \\ Department of Agriculture and Animal Health, University of South Africa, Pretoria, South Africa \\ (e-mail: kaluchimdimang@yahoo.com; phone: +27-748-366-063) \\ *Corresponding author \\ e-mail:ntushk@unisa.ac.za; phone: +27-789-027-944
}

(Received 28 $8^{\text {th }}$ May 2019; accepted $11^{\text {th }}$ Oct 2019)

\begin{abstract}
The production of acid mine drainage (AMD) is among the factors responsible for much of the degradation of water and soil resources and the disruption of biodiversity in the environment. Several studies have shown that organisms (either macro or micro) present at sites contaminated with AMD have the potential to bioaccumulate heavy metals and hence stimulate their application in bioremediation processes. Algal strains are not an exception to those organisms found in AMD. This review was aimed at examining the heavy metal remediation of AMD using algae, remediation properties of algae and different algal-based methods used in heavy metal remediation of AMD. Algal strains such as Spirulina sp., Chlorella spp., Scenedesmus spp., Cladophora spp., Oscillatoria spp., Anabaena spp. and Phaeodactylum tricornutum act as "hyper-accumulators" and "hyper-adsorbents" with a high selectivity for different elements from AMD. However, algae-based methods of abating AMD are not the ultimate solution to the problem and there is room for more studies. The current study suggests further attention to phycoremediation individually and synergistically with sulphate-reducing bacteria.

Keywords: bioremediation, hyperaccumulation, phycoremediation, phytoremediation, sulphate-reducing bacteria
\end{abstract}

Abbreviations: AMD: acid mine drainage, HRAP: high-rate algal ponds, SRB: sulphate-reducing bacteria, ATS: algal turf scrubber, PIMR: pipe inserted microalgae reactor

\section{Introduction}

Industrialisation has brought immense development and economic improvement to most countries of the world. Despite the positive impact of industrialization, it also has negative effects on the environment and biodiversity. Acid mine drainage (AMD) is one of the negative consequences of industrialisation. The mining of gold $(\mathrm{Au})$, copper $(\mathrm{Cu})$, nickel $(\mathrm{Ni})$ and other minerals are associated with AMD, which may have adverse effects on human and animal health as well as the environment (Azapagic, 2004). Conventional approaches to remediation and other active and passive technologies have been adopted to neutralise the threat of AMD. However, they have been found to have many drawbacks, including high cost of application and further and unforeseen environmental damage. The option of using green technologies in remediating AMD has been researched and applied in many countries, and offers much promise for a cleaner and safer environment (Galiulin and Galiulina, 2003, 2008; Koptsik et al., 2014; Cunningham and Ow, 1996; Nowack et al., 2006; Prasad and Freitas, 2003). These green technologies involve, among others, the use of algae that offer solutions without causing any adverse effects on the environment.

The process of using macro- and microalgae to remediate AMD and other contaminated environments is termed phycoremediation. Kalin et al. (2006) state that the use of algae as decontaminating agents provides some advantages, including low costs of operation, easy manipulation, lack of pollution, relatively simple recovery of 
the metal contaminants for recycling and not constituting a source of secondary waste. The accumulated heavy metals can be recovered after the growth of algae in the contaminated environment by separating the algal biomass from the water. The separated algal biomass is dried and the heavy metals are recovered by converting the heavy metals into oxides or other recoverable salts. In addition, the separated algal biomass can either be sequestered or stored for future purposes or disposed of in municipal waste landfills to reduce its environmental footprint (Edmundson and Wilkie, 2013).

Compared to the conventional method of remediation, phycoremediation has been shown to be less costly, less energy consuming and with no generation of sludge (Ghosh and Singh, 2005; Abdel-Raouf et al., 2012). In phycoremediation, macro- or microalgae are used for the removal or biotransformation of pollutants from wastewater (Ahmad et al., 2013). Algae of the genera Chlorella, Chlamydomonas, Spirulina, Scendesmus, Nostoc and Oscillatoria have been used in wastewater treatment over the last few decades (Dubey et al., 2011; Sharma and Khan, 2013). It was assumed that microalgae are versatile in converting contaminants into a non-hazardous material, making the treated water fit for reuse or discharge into receiving water bodies (Rao et al., 2011). Algae-based treatment can be used in combination with secondary treatment where microorganisms work in symbiosis with algae cells for effective treatment.

The remediation of AMD by using algae has been the focus of many studies since the ability of algae to adsorb and actively transport heavy metals through the cellular tissues was identified (Stevens et al., 2001; Malik, 2004; Das et al., 2009; Mehta and Gaur, 2005). The transported heavy metals can be intracellularly immobilized by metalbinding peptides found in the vacuoles of the cells and stored in the cytoplasm through the synthesis of polyphosphate bodies (Pawlik-Skowrońska, 2001; Priya et al., 2014). Nishikawa et al. (2003) point out that algal cells are composed of electron-dense bodies made up of polyphosphate that are capable of accumulating metals and protecting algal cells from metal toxicity. Irrespective of the ability of algae to remediate water contaminated by heavy metal, the species of algae prospected to be used in bioremediation of heavy metals in AMD must be able to tolerate highly concentrated mixtures of distinct heavy metals. In this review, heavy metal remediation of AMD is examined. In addition, the heavy metal remedial properties of algae and the different methods involving algal strains in heavy metal remediation of AMD are reviewed. Topics under discussion include remediation properties of algae and an overview of different algal-based methods used in heavy metal remediation of AMD.

\section{Heavy metal remediation of acid mine drainage using algal strains}

Intense mining leads to the production of AMD, which has detrimental effects on the environment - hence the need to control and possibly manage the waste and acidic water produced by mines. Conventional treatment methods have been widely researched and applied in the remediation of AMD (Gazea et al., 1996; Robinson and Robb, 1995; Ghosh and Singh, 2005; Abdel-Raouf et al., 2012). A medium-sized mining operation may spend over US\$70 000 annually on the cost of lime alone, making conventional treatment methods expensive (Gazea et al., 1996; Robinson and Robb, 1995; Ghosh and Singh, 2005; Abdel-Raouf et al., 2012).

Harris and Ramelow (1990) point out that research has been done on the use of algal strains in bioremediation but the main focus has been the metal ion accumulation 
abilities of some algae species from solutions. McKnight and Morel (1980) report that complex metal ions forming chelatins and polysaccharides produced in algae strains have been extensively studied to enhance the knowledge of heavy metal remediation by algae. Shiraiwa et al. (1993) discovered the ability of certain strains of algae to increase the alkalinity of the medium as a by-product of their inorganic carbon accumulating mechanism. However, the use of this alkaline production by algae in precipitation of metals in AMD has not been widely reported.

Some researchers have shown that direct treatment of AMD with an algal culture has a short period of effectiveness and the sustainability of this direct treatment is poor (Wallace et al., 1997; Boshoff et al., 1996). $\mathrm{Cu}$, lead (Pb) and zinc ( $\mathrm{Zn}$ ) are toxic to algal species such as Spirulina sp. when the accumulated concentrations of these metals exceed $7 \mu \mathrm{mol} / \mathrm{g}$ (Payne et al., 1999). Van Hille et al. (1999) developed a system that separates the growing culture of algae from the untreated effluent to help solve the problem of heavy metal toxicity in Spirulina sp. The system combines the principles of passive treatment with simple, low-cost reactors associated with active treatment methods. Furthermore, Van Hille et al. (1999) utilized the alkalinity produced by the alga Spirulina sp. in a continuous system and found that the alkaline environment elicited by the algal strain enhanced heavy metal precipitation. According to their findings, the primary treatment process consistently removed between 80 and $95 \%$ of $\mathrm{Zn}(7.16 \mathrm{mg} / \mathrm{l})$, over $99 \%$ of iron $(\mathrm{Fe})(98.9 \mathrm{mg} / \mathrm{l})$ and $\mathrm{Pb}(2.35 \mathrm{mg} / \mathrm{l})$ within 14 days. Van Hille et al. (1999) further discovered that the combination of the primary and secondary treatments enhanced the removal of over $95 \%$ of all metals tested as well as a $90 \%$ reduction in sulphate concentration.

Recently, Oberholster et al. (2018) grew Microspora tumidula, Oedogonium crassum and Klebsormidium klebsii previously established by Oberholster et al. (2014) under laboratory conditions for $192 \mathrm{~h}$ to determine their bioaccumulation of sulphur (S) and other important algal growth elements such as calcium $(\mathrm{Ca})$, magnesium $(\mathrm{Mg})$ and phosphorus (P) from AMD water and treatment constructed wetland water in the vicinity of the Boesman Spruit (stream) near the town of Carolina in the Ermelo coalfield in South Africa at different $\mathrm{pH}$ values. They observed that Microspora tumidula showed the highest bioaccumulation of $\mathrm{S}$ and $\mathrm{P}$ at a $\mathrm{pH}$ of 5 and Oedogonium crassum showed the highest bioaccumulation of $\mathrm{Ca}$ and $\mathrm{Mg}$ at a $\mathrm{pH}$ of 7 . The accumulation efficiency of $\mathrm{Mg}$ by all three macroalgal species increased significantly with an increase in the $\mathrm{pH}$. Oedogonium crassum and Klebsormidium klebsii showed very little increase in chlorophyll $\mathrm{A}\left(\mathrm{mg} \mathrm{g}^{-1} \mathrm{fw}\right)$ and ash-free dry weight $\left(\mathrm{mg} \mathrm{g}^{-1}\right.$ AFDW) when compared to the species $M$. tumidula at all four $\mathrm{pH}$ ranges. In conclusion, their study established Microspora tumidula as a good candidate for use in a biological hybrid system for treating sulphur-rich AMD.

\section{Remediation properties of algal biomass}

The removal of heavy metals and sulphates by algae is believed to be very flexible and depends on the type of metal, the taxon of the alga and the age of material to be removed (Novis and Harding, 2007). Studies have shown that the removal of heavy metals and other contaminants by algae is influenced by seasons (Elbaz-Poulichet et al., 2000; Brake et al., 2004). The seasons influence the availability of light and temperature range, and this can in turn affect the rate of bioremediation by algae because of their sensitivity to light intensity and temperature. 
The common mechanisms used by algae in the remediation process are absorbency and adsorbency. Heavy metal remediation is dependent on the species of algae. The algae feed on the nutrient elements during the process of heavy metal removal and there is an increase in their biomass. Some of these heavy metals adhere to the surface of algae (adsorbency) and others are taken up into the inner cells (absorbency) of the algae. An aqueous solution is required by algae in the removal of a low concentration of metal ions and the bioaccumulation of these metals in their cells (Afkar et al., 2010; Chen et al., 2012; Kumar and Gaur, 2011; Mehta and Gaur, 2005). The heavy metals are bioaccumulated in the cell vacuoles, intercellular spaces and cell wall (Afkar et al., 2010; Chen et al., 2012; Kumar and Gaur, 2011; Mehta and Gaur, 2005), as shown in Figure 1. Vymazal (1984) observed that Cladophora glomerata and Oedogonium rivulare are among the species used to continuously remove cobalt $(\mathrm{Co}), \mathrm{Ni}, \mathrm{Pb}$, cadmium $(\mathrm{Cd})$, manganese $(\mathrm{Mn}), \mathrm{Fe}$, chromium $(\mathrm{Cr})$ and $\mathrm{Cu}$ from wastewater. The ability and extent of heavy metal removal by algae is believed to vary from strain to strain (Al-Shwafi and Rushdi, 2008). Mehta and Gaur (2005) discovered that dead algae biomass adsorbs more heavy metals than living ones. Pawlik-Skowrońska (2001) observed that the freshwater algae Stigeoclonium spp. can thrive well and effectively remove $\mathrm{Zn}$ in mining water containing a high concentration of $\mathrm{Zn}$.

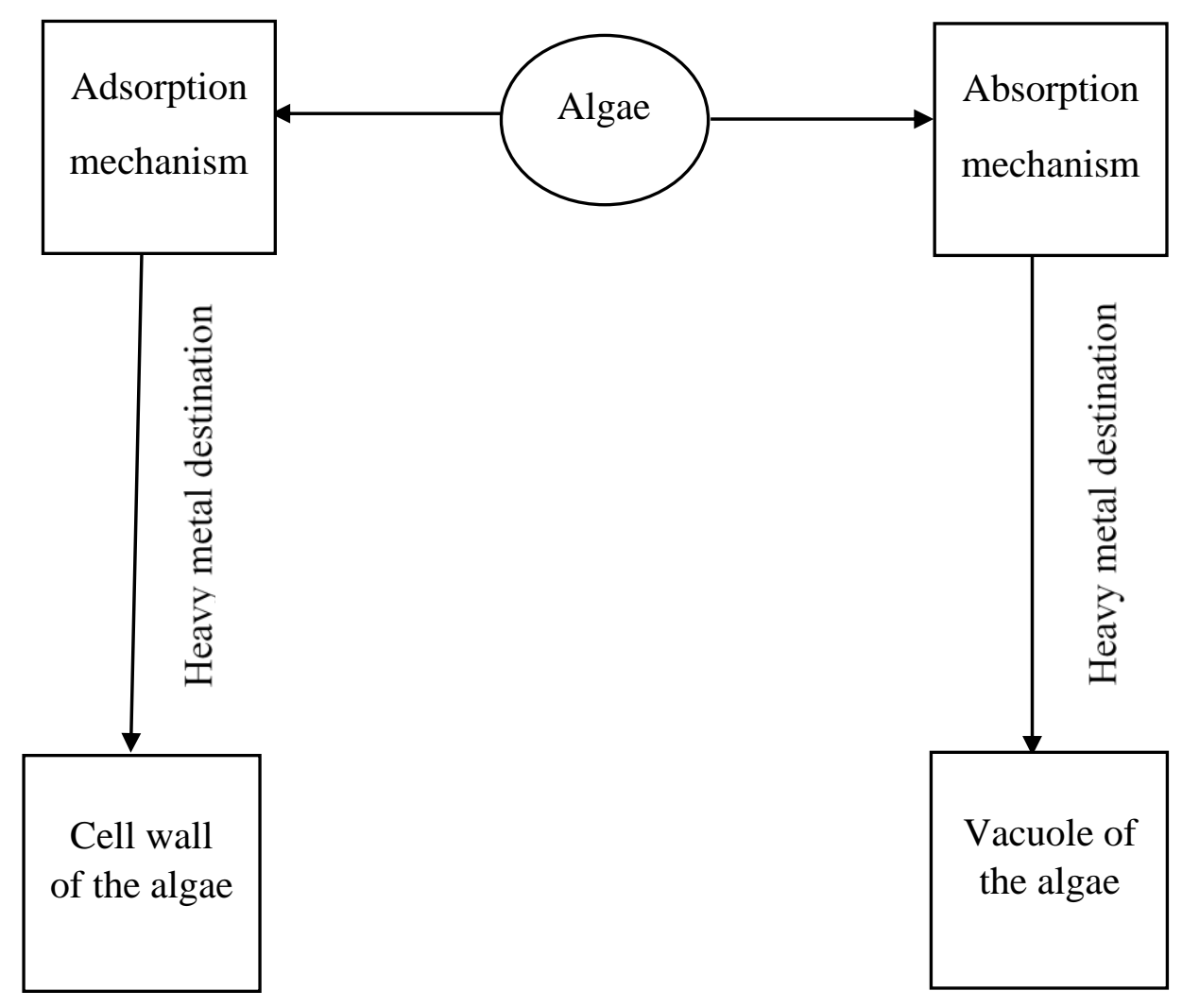

Figure 1. Mechanisms of heavy metal remediation and their destination in algae

Living algae accumulate trace metals intracellularly through active biological transport (Ajjabi and Chouba, 2009; Kiran and Thanasekaran, 2011). The synergic activity of different types of algae, along with their multilayer cell walls, makes them a suitable adsorbent for heavy metals (Bilal et al., 2013; Gupta et al., 2015; Wang and 
Chen, 2009). Algae can survive in both fresh and marine brackish waters and are among the most commonly found photosynthetic eukaryotes (Ioannis and Kyzas, 2015). Bishnoi and Pant (2004) discovered that Spirogyra algal species were able to remove $\mathrm{Cu}$ (II) with an efficiency of 58 to $85 \%$ at an initial concentration of $20 \mathrm{mg} / \mathrm{l}$ after $30 \mathrm{~min}$. Furthermore, Pavasant et al. (2006) found that Caulerpa lentillifera (a dried green macroalga) was also effective in the removal of multiple metals in an aqueous solution through adsorbency. Other algae such as the brown alga Turbinaria ornate and the green alga Ulothrix zonata were also found to be very effective adsorbents in the removal of heavy metals (Nuhoglu et al., 2002; Vijayaraghavan and Prabu, 2006; Djati et al., 2016). Regarding the tolerance of Ulothrix sp. LAFIC 010 (Chlorophyta) for a high concentration of metals from ACD in Brazil, Massocato et al. (2018) found that the algae accumulated $\mathrm{Mn}$ and $\mathrm{Ni}$ in their cell walls and vacuole respectively.

Microbial sulphate reduction generates alkalinity and this promotes the bioremediation of acid mine drainage through the formation of metal sulphides that allows for the precipitation of metals from the solution. Acid mine drainage environments are known to be deficient of natural carbon (Koschorreck, 2008), and the addition of suitable carbon sources promotes the activity of sulphate-reducing bacteria (SRB) (Zhang et al., 2017). For SRB to survive and for their better growth, nutrients such as yeast extract and tryptone are absolutely necessary (Zhang et al., 2017). Kiran et al. (2017) state that the most studied bioremediation for heavy metals removal is based on SRB which cause metal sulphide precipitation and hence the removal of the metals from the contaminated environment. The use of SRB to remove heavy metals was successful on a large scale for heavy metal removal at low $\mathrm{pH}$ values, stable sludge, very low operating costs and minimal energy consumption. Based on this, SRB could provide an on-site alternative treatment method for AMD; however, they may not be suitable for sites with low temperatures such as those in extreme winter conditions (Sheoran et al., 2010).

The use of SRB for the remediation of the contaminated environment has the weakness of long residence times that can last for weeks. Furthermore, a constant supply of organic substrates and the use of large steel bioreactors are required for them to be effective (White et al., 1997; Sheoran et al., 2010). SRB also require time to grow and reach the critical population growth level to work effectively. This can be a cost of remediation. However, the greatest advantage of using SRB to remediate the environment is their ability to remove both metals and sulphates simultaneously. This is not common when the traditional chemical remediation process is used (Kiran et al., 2017).

\section{Overview of remediation methods of acid mine drainage using algal strains}

Various policies, regulations and standards have been suggested in many countries to prevent the threat of AMD to human health and the environment, to reduce the concentrations of the pollutants and to develop cost-effective technologies that will enhance AMD remediation (Fan, 1996). This is due to the challenge that AMD has imposed on most countries of the world (Nriagu and Pacyna, 1988). The conventional treatment methods which are based on either separation (such as precipitation, adsorption and filtration) or reaction have shown many weaknesses, such as low removal capacity, lack of selectivity and intolerance to organic substances. 
The high-rate algal pond (HRAP) system is believed to be the most frequently used method for remediating AMD (Oswald, 1998; Mehrabadi et al., 2015). In addition, the algal turf scrubber (ATS) was also developed to remediate AMD and polluted groundwater. The ATS method involves the application of suspended biomass of cyanobacteria such as Spirulina, Oscillatoria, Anabaena or consortia of species or common green algae species such as Chlorella, Scenedesmus, Cladophora (Craggs et al., 1996; Adey et al., 1996). These methods were found to be effective in the removal of heavy metals and organic compounds such as chlorinated and aromatic organic compounds to acceptable levels in AMD or any other industrial wastewater (Craggs et al., 1996; Adey et al., 1996).

Toumi et al. (2000) reported that the HRAP has a higher removal rate per unit volume per day. Tested on urban polluted water with lower ion concentrations of $\mathrm{Zn}$, $\mathrm{Cu}$ and $\mathrm{Pb}$, the HRAP was found to be 10 times more efficient in removing $\mathrm{Cu}$ compared to the waste stabilization pond system. Furthermore, high $\mathrm{pH}$ values enhanced metal precipitation and effective algal photosynthesis. Rose et al. (1998) reported the formation of a patent ATS formed from a combination of HRAP and SRB. This process involves the direct addition of AMD into HRAP with a high $\mathrm{pH}$ value to enhance the precipitation of heavy metals, followed by the recovering of HRAP biomass which is used as a carbon source for SRB (Perales-Vela et al., 2006). However, these methods had challenges in maintaining a dynamic equilibrium between algae net oxygen production, bacterial respiration due to low light penetration, rich microalgal biomass, climate conditions and proper mixing (Fallowfield and Garret, 1985).

Phillips et al. (1995) suggest non-agitated algal ponds as a remedy for the challenges faced with constructed wetland technologies in enhancing the effective removal of $\mathrm{Mn}$ and stability of a neutralizing $\mathrm{pH}$. They show that consortia of algae and cyanobacteria can reduce Mn concentrations effectively to an environmentally safe level. The work done by Perales-Vela et al. (2006) also shows that Mn can be removed through biomass adsorption, high $\mathrm{pH}$ precipitation and immobilization. All these findings provide a promising future for the treatment of AMD and wastewaters through algae bioremediation.

Dinardo et al. (1991) state that the history of the ability of aquatic plants to remove heavy metals efficiently from contaminated AMD water dates back to 1973. Since then, several algae strains have been successfully used in the removal of heavy metals from AMD or wastewater but most of the work was completed during a batch process in which microalgal species were grown. Wang et al. (2016) state that algae can produce oxygen at a lower cost and also be effective in phycoremediation.

Algae play an essential role in the bioaccumulation of heavy metals in wetland remediation of AMD. Zagury et al. (2007) state that this role of algae makes it possible to design passive bioreactor systems for the remediation of AMD. A passive bioreactor system is based on a similar principle as a large activated carbon filter where AMD comes into the surface area, percolates through a specially constructed barrier layer and exits the system from below. The major components of this bioreactor, especially the initial stage, include algae. Spirulina spp. was discovered to be useful in remediating AMD because they were able to absorb various heavy metals rapidly through direct contact with the AMD effluent stream and reached saturation within 30 min (Van Hille et al., 1999; Balaji et al., 2014). Furthermore, it was observed that Spirulina spp. exhibited toxicity after the period of saturation but continued to generate an alkaline environment capable of reducing the acidity of AMD through the production of 
inorganic bicarbonate salts. Species of both micro- and macroalgae have been identified as useful in phycoremediation. A Chlorella strain that was capable of sustaining growth at $11.24 \mathrm{mg}$ of $\mathrm{Cd}^{2+} / 1$ was analysed in a marine screen and was found to have a removal efficiency of $65 \%$ when exposed to an amount of $5.62 \mathrm{mg}$ of $\mathrm{Cd}^{2+} / 1$ (Matsunaga et al., 1999). Furthermore, Chlorella and Scenedesmus strains were analysed in a batch process at $20 \mathrm{mg} \mathrm{Cr}^{6+} / 1$ and were found to have removal efficiencies of $48 \%$ and $31 \%$ respectively (Travieso et al., 1999).

Algal biomass was observed to accumulate heavy metals in the work done by Freitas et al. (2011) on the biosorption of heavy metals by algal species in AMD from coal mining in Brazil. They further observed that the algal biomass' capabilities to absorb the heavy metals were $\mathrm{Fe}>\mathrm{Al}>\mathrm{Ca}>\mathrm{Mg}>\mathrm{Zn}>\mathrm{Mn}>\mathrm{Cu}$ in all the sampling sites. Algal genera such as Microspora, Eunotia, Euglena, Mougeotia and Frustulia survived in the AMD environment and Microspora was the most dominant (Freitas et al., 2011). A hybrid system comprising a pipe inserted microalgae reactor (PIMR) and an active treatment unit for the removal of Fe from AMD was used by Park et al. (2013) to study the removal of heavy metals by algal species. Fe can hinder the growth of algae and lipid formations which can limit the ability of algal biomass to remove heavy metals in AMD, hence the need to remove the element in the hybrid system. Furthermore, in the study carried out by Park et al. (2013), Nephroselmis sp. was observed to be effective in removing heavy metals and had a strong tendency to grow with pre-treated AMD. Based on the ability of the algal species to grow well and also remove heavy metals, PIMR was suggested to be more effective in removing heavy metals and enhancing the growth of algal species. PIMR was found to be more protective than HRAP and SRB in protecting the algal species against environmental contaminants. However, the HRAP system has more treatment capacity and heavy metal removal than the PIMR system.

At least 14 algal species and their ability to take up heavy metal contaminants from AMD and other pollution sources were reviewed by Ben and Baghour (2013), and were found to hyperaccumulate or hyperabsorb heavy metals with high selectivity for different metals. Furthermore, the results of a few studies regarding the use of some microalgae species for AMD bioremediation were compiled by Das et al. (2009). The removal efficiencies of heavy metals and sulphates which are the main contaminants in AMD, operating conditions and the growth methods used to achieve the results, and the effectiveness and possibility of algae technology for AMD bioremediation are contained in Table 1. $\mathrm{Cu}, \mathrm{Zn}, \mathrm{Fe}, \mathrm{Pb}, \mathrm{Ni}, \mathrm{Mn}$ and sulphates, under a known $\mathrm{pH}$ range, can be removed by microalgae. This knowledge about microalgae enhances the possibility of modifying phycoremediation of the algal biomass to suit specific pollutant conditions, alongside both uptake limits and specificity through genetic engineering of algal species.

Since the early 1990s, passive water treatment systems where algae remove heavy metals from AMD or other contaminated wastewater as a common component have been used. Although the algal biomass has been proven to be efficient in removing both organic and inorganic pollutants, there is a need for more studies to explore its full potential with the development of innovative technologies. Such innovative technologies could include gene modification technology. This technology involves identifying specific genes responsible for producing metal-chelating proteins and enhancing this capability in algal strains. 
Table 1. Summary of the use of some algal species in acid mine drainage bioremediation (adapted from Das et al., 2009)

\begin{tabular}{|c|c|c|c|c|}
\hline Algal strains & Remediation role & Achieved results & Growth method & Reference \\
\hline $\begin{array}{l}\text { Blue-green algae - } \\
\text { cyanobacterial mat }\end{array}$ & & Removal of $2.59 \mathrm{~g}$ of $\mathrm{Mn} / \mathrm{day} / \mathrm{m}^{2}$ & Oxidation pond & Phillips et al. (1995) \\
\hline Spirulina sp. & $\begin{array}{l}\text { Metal adsorption, re- } \\
\text { alkalization, nutrient } \\
\text { for SRB (dead } \\
\text { biomass) }\end{array}$ & $\begin{array}{c}\text { (i) Removal of } \mathrm{Fe} \text { (up to } 100 \%), \mathrm{Zn}(86-98 \%), \mathrm{Cu}(38-76 \%), \mathrm{Pb} \\
\text { (40-78\%) at retention time of } 10 \text { days } \\
\text { (ii) Rise of } \mathrm{pH} \text { from } 3 \text { to } 8.5 \text { for a biomass loading of } 3 \mathrm{mg} / \mathrm{mL} \\
\text { chlorophyll A }\end{array}$ & $\begin{array}{l}\text { HRAP (high-rate algal } \\
\text { pond) }\end{array}$ & Rose et al. (1998) \\
\hline Spirulina sp. & $\begin{array}{l}\text { Alkalinity generation } \\
\text { and metal precipitation }\end{array}$ & $\begin{array}{c}\text { (i) } \mathrm{pH} \text { rise from } 1.8 \text { to } 8.18 \\
\text { (ii) Reduction of sulphates }\left(\mathrm{SO}_{4}\right) 89 \%, \mathrm{Fe} 99 \%, \mathrm{~Pb} 95 \%, \mathrm{Zn} 93 \% \text {, } \\
\mathrm{Cu} 94 \%\end{array}$ & $\begin{array}{c}\text { Bench scale anaerobic } \\
\text { digester, primary and } \\
\text { secondary treatment }\end{array}$ & $\begin{array}{l}\text { Van Hille et al. } \\
\text { (1999) }\end{array}$ \\
\hline Mixed algal population & $\begin{array}{c}\text { Soluble EPS as carbon } \\
\text { source for SRB }\end{array}$ & $\begin{array}{l}\text { Up to } 57 \% \text { of sulphates }\left(\mathrm{SO}_{4}\right) \text { and } 52 \% \text { COD removal by mixed } \\
\qquad \text { SRB }\end{array}$ & HRAP & $\begin{array}{l}\text { Molwantwa et al. } \\
\quad(2000)\end{array}$ \\
\hline $\begin{array}{l}\text { Eunotia exigua and } \\
\text { Pinnularia obscura }\end{array}$ & Primary production & Chlorophyll A (Chl A) Content 52-72 mg/m² & Mining lake & $\begin{array}{l}\text { Koschorreck et al. } \\
\text { (2002) }\end{array}$ \\
\hline Spirulina spp. & $\begin{array}{l}\text { Dead biomass as } \\
\text { nutrient for SRB }\end{array}$ & $150 \mathrm{mg} \mathrm{SO}_{4} \mathrm{removal} / \mathrm{g}$ algal biomass/day & $\begin{array}{l}\text { Bench scale anaerobic } \\
\text { upflow reactor }\end{array}$ & $\begin{array}{l}\text { Boshoff et al. } \\
\quad(2004)\end{array}$ \\
\hline $\begin{array}{l}\text { Blue-green algae } \\
\text { (predominantly } \\
\text { Oscillatoria spp.)- } \\
\text { microbial consortium }\end{array}$ & $\begin{array}{l}\mathrm{SO}_{4} \text { removal, metal } \\
\text { precipitation by } \\
\text { consortium }\end{array}$ & $\begin{array}{l}\text { (i) } \mathrm{pH} \text { increase from } 2.93 \text { to } 6.78 \\
\text { (ii) Reduction of } \mathrm{SO}_{4} 29 \%, \mathrm{Fe} 95 \%, \mathrm{~Pb} 88 \%, \mathrm{Zn} 86 \%, \mathrm{Cu} 97 \% \text {, } \\
\mathrm{Co} 83 \%, \mathrm{Ni} 62 \%, \mathrm{Mn} 45 \% \text {. }\end{array}$ & Bench scale test cell & $\begin{array}{c}\text { Sheoran and } \\
\text { Bhandari (2005) }\end{array}$ \\
\hline Chlorella ellipsoidea & $\begin{array}{l}\text { Bioremediation } \\
\text { potential }\end{array}$ & & $\begin{array}{l}\text { In-situ test using } \\
\text { limnocorrals }\end{array}$ & EPA (2005) \\
\hline $\begin{array}{l}\text { Eunotia exigua and } \\
\text { Chlamydomonas sp. }\end{array}$ & $\begin{array}{l}\text { Enhance primary } \\
\text { production, thereby } \\
\text { SRB growth }\end{array}$ & $\begin{array}{l}\text { Reduction of } \mathrm{Fe} \text { from } 14 \mathrm{mg} / \mathrm{L} \text { to } 0.2 \mathrm{mg} / \mathrm{L} \text { and } \mathrm{SO}_{4} \text { from } 344 \\
\mathrm{mg} / \mathrm{L} \text { to } 124 \mathrm{mg} / \mathrm{L}\end{array}$ & Microcosm experiment & Fyson et al. (2006) \\
\hline Ulothrix spp. & Metal absorption & Absorption of $\mathrm{Cu} 3500 \mathrm{mg} / \mathrm{L}$ and $\mathrm{As} 500 \mathrm{mg} / \mathrm{L}$ & $\begin{array}{l}\text { AMD, Sar Cheshmeh } \\
\text { copper mine }\end{array}$ & Orandi et al. (2007) \\
\hline
\end{tabular}


The knowledge of the use of algae and their ability to remove heavy metals is widely accepted and growing fast. However, significant contributions are yet to be made in light of the success of passive systems used in the remediation of AMD. Many researchers have focused on the production of biofuel or biodiesel from algal sources. This has taken the attention of most researchers away from the potential value of algae in phycoremediation which presents a promising solution in AMD remediation. Das et al. (2009) encourage the use of Lepocinclis sp. and Klebsormidium sp. in the treatment of AMD because they showed promising features in terms of their growth and distribution. Furthermore, the use of a consortium of algae and fungi has been encouraged, either used individually or as a group, as they offer the advantage of working in symbiosis and synergy. However, this consortium of algae and fungi could bring the challenges of high heavy metal concentrations, acidity, low availability of organic carbon and phosphates because these factors affect the growth of both organisms. This can be a setback to the success of using this consortium of algae and fungi in treating AMD because it contains high levels of heavy metals with a very low $\mathrm{pH}$.

\section{Conclusion}

Many studies have indicated the effectiveness of phycoremediation of AMD and its potential for future applications, as shown in this current review. It is also evident from this review that passive systems involving the use of algal biomass have achieved commendable results; however, they are not the ultimate solution to the problem of AMD. Consequently, there is a need for further studies on effective remediation of AMD to provide more solutions to the environmental problem caused by this scourge. It is believed that each AMD tailing site has unique chemical characteristics and compositions that require a unique way of remediation.

Therefore, a conclusive study will require evaluation of various algae species, their removal mechanisms and growth, $\mathrm{pH}$, temperature, residence time and flow rate of the AMD to enhance the success of AMD remediation using algae species. Some algae species are known as extremophiles because they can thrive well in unusual and extreme environmental conditions. As a result, there is a need to study in detail their adaptability to be used in phycoremediation processes, especially for AMD. However, algae as sources of oxygen have some weaknesses such as their unpredictable response to a complex changing environment or wastewater when compared to conventional wastewater treatment plants. Furthermore, the opacity of the medium, solar radiation, rise of nutrients, temperature, season and ecological succession, and other major environmental factors are not easily understood and require careful monitoring to ensure the success of the process.

This current review suggests that more studies should be done on different aspects of phycoremediation and SRB approaches, and possibly a combination of the two approaches in the remediation of AMD. This should range from identifying and developing simple, effective physical barrier materials to advanced genetic research suitable for AMD.

Acknowledgements. The authors are grateful to the Agricultural Research Council and University of South Africa Climate Change Collaboration Centre for funding. 


\section{REFERENCES}

[1] Abdel-Raouf, N., Al-Homaidan, A. A., Ibraheem, I. B. M. (2012): Microalgae and wastewater treatment. - Saudi Journal of Biological Sciences 19: 257-275.

[2] Adey, W. H., Luckett, C., Smith, M. (1996): Purification of industrially contaminated groundwaters using controlled ecosystems. - Ecological Engineering 7(3): 191-212.

[3] Afkar, A., Ababna, H., Fathi, A. A. (2010): Toxicological response of the green alga Chlorella vulgar to some heavy metals. - American Journal of Environmental Science 6: 230-237.

[4] Ahmad, F., Khan, A. U., Yasar, A. (2013): Comparative phycoremediation of sewage water by various species of algae. - Proceedings of the Pakistan Academy of Science 50: 131-139.

[5] Ajjabi, L. C., Chouba, L. (2009): Biosorption of $\mathrm{Cu}^{2+}$ and $\mathrm{Zn}^{2+}$ from aqueous solutions by dried marine green macroalga Chaetomorpha linum. - Journal of Environmental Management 90: 3485-3489.

[6] Al-Shwafi, N. A., Rushdi, A. I. (2008): Heavy metal concentrations in marine green brown and red seaweeds from coastal waters of Yemen, the Gulf of Aden. Environmental Geology 55: 653-660.

[7] Azapagic, A. (2004): Developing a framework for sustainable development indicators for the mining and minerals industry. - Journal of Cleaner Production 12(6): 639-662.

[8] Balaji, S., Kalaivani, T., Rajasekaran, C. (2014): Biosorption of zinc and nickel and its effect on growth of different Spirulina strains. - CLEAN - Soil, Air, Water 42(4): $507-$ 512.

[9] Ben, C. K., Baghour, M. (2013): The role of algae in phytoremediation of heavy metals: a review. - Journal of Material and Environmental Science 4: 873-880.

[10] Bilal, M., Shah, J. A., Ashfaq, T., Gardazi, S. M. H., Tahir, A. A., Pervez, A., Haroon, H., Mahmood, Q. (2013): Waste biomass adsorbents for copper removal from industrial wastewater - a review. - Journal of Hazardous Materials 263: 322-333.

[11] Bishnoi, N. R., Pant, A. (2004): Biosorption of copper from aqueous solution using algal biomass. - Journal of Scientific and Industrial Research 113: 813-816.

[12] Boshoff, G. A., Duncan, J. R., Rose, P. D. (1996): An algal-bacterial integrated ponding system for the treatment of mine drainage waters. - Journal of Applied Phycology 8: 442.

[13] Boshoff, G. A., Duncan, J. R., Rose, P. D. (2004): The use of micro-algal biomass as a carbon source for biological sulphate reducing systems. - Water Research 38: 2659-2666.

[14] Brake, S. S., Hasiotis, S. T., Dannely, H. K. (2004): Diatoms in acid mine drainage and their role in the formation of iron-rich stromatolites. - Geomicrobiology Journal 21: 331340.

[15] Chen, C., Chang, H., Kao, P., Pan, J., Chang, J. (2012): Biosorption of cadmium by $\mathrm{CO}_{2-}$ fixing microalga Scenedesmus obliquus CNW-N. - Bioresource Technology 105: 74-80.

[16] Craggs, R. J., Adey, W. H., Jenson, K. R., St. John, M. S., Green, G. F., Oswald, W. J. (1996): Phosphorous removal from wastewater using and algal turf scrubber. - Water Science Technology 33: 191-198.

[17] Cunningham, S. D., Ow, D. W. (1996): Promises and prospects of phytoremediation. Plant Physiology 110: 715-719.

[18] Das, B. K., Roy, A., Koschorreck, M., Mandal, S. M., Potthoff, K. W., Bhattachary, J. (2009): Occurrence and role of algae and fungi in acid mine drainage environment with special reference to metals and sulfate immobilization. - Water Research 43: 883-894.

[19] Dinardo, O., Kondos, P. D., MacKinnon, D. J., McCready, R. G. L., Riveros, P. A., Skaff, M. (1991): Study on Metals Recovery/Recycling from Acid Mine Drainage. - Phase IA: Literature Survey, for MEND Treatment Committee.

[20] Djati, U. H., Tan, K. X. D., Choong, Z. Y. D., Yu, J. J., Ong, J. J., Lim, Z. B. (2016): Biosorption of heavy metal by algae biomass in surface water. - Journal of Environmental Protection 7: 1547-1560. 
[21] Dubey, S. K., Dubey, J., Mehra, S., Tiwari, P., Bishwas, A. J. (2011): Potential use of cyanobacteria species in bioremediation of industrial effluent. - African Journal of Biotechnology 10: 1125-1132.

[22] Edmundson, S. J., Wilkie, A. C. (2013): Landfill leachate - a water and nutrient resource for algae-based biofuels. - Environmental Technology 34: 1849-1857.

[23] Elbaz-Poulichet, F., Dupuy, C., Cruzado, A., Velasqaez, Z., Achterberg, E. P., Braungardt, C. B. (2000): Influence of sorption process by iron oxides and algae fixation on arsenic and phosphate cycle in an acidic estuary (Tinto River, Spain). - Water Research 34: 3222-3230.

[24] Environmental Protection Agency (EPA) (2005): Algal Bioremediation of the Berkeley Pit Lake System: An In-Situ Test Using Limnocorrals. - EPA, Washington.

[25] Fallowfield, H. J., Garret, M. K. (1985): The photosynthetic treatment of pig slurry in temperate climatic conditions: a pilot plant study. - Agricultural Wastes 12: 111-136.

[26] Fan, A. M. (1996): Assessment of Metals in Drinking Water with Specific References to Lead and Arsenic. - In: Chang, L. W. (ed.) Toxicology of Heavy Metals. CRC Press Inc., Boca Raton, FL, pp. 39-53.

[27] Freitas, A. P. P., Schneider, I. A. H., Schwartzbold, A. (2011): Biosorption of heavy metals by algal communities in water streams affected by the acid mine drainage in the coal-mining region of Santa Catarina state, Brazil. - Mineral Engineering 24: 1215-1218.

[28] Fyson, A., Nixdorf, B., Kalin, M. (2006): The acidic lignite pit lakes of Germany microcosm experiment on acidity removal through controlled eutrophication. Ecological Engineering 28: 288-295.

[29] Galiulin, R. V., Galiulina, R. A. (2003): Phytoextraction of heavy metals from contaminated soils. - Agrokhimiya 3: 77-85.

[30] Galiulin, R. V., Galiulina, R. A. (2008): Soil purification from heavy metals with the help of plants. - Vestnik Rossiiskoi Akademii Meditsinskikh Nauk 78: 247-249.

[31] Gazea, B., Adam, K., Kontopoulos, A. (1996): A review of passive systems for the treatment of acid mine drainage. - Minerals Engineering 9: 23-42.

[32] Ghosh, M., Singh, S. P. (2005): A review of phycoremediation of heavy metals and utilization of its by- products. - Asian Journal on Energy and Environment 6: 214-231.

[33] Gupta, V. K., Nayak, A., Agarwal, S. (2015): Bioadsorbents for remediation of heavy metals: current status and their future prospects. - Environmental Engineering Research 20: $1-18$.

[34] Harris, P. O., Ramelow, G. J. (1990): Binding of metal ions by particulate biomass derived from Chlorella vulgaris and Scenedesmus quadricauda. - Environmental Science and Technology 24: 220-228.

[35] Ioannis, A., George, Z. K. (2015): Progress in batch biosorption of heavy metals onto algae. - Journal of Molecular Liquids 209: 77-86.

[36] Kalin, M., Fyson, A., Wheeler, W. N. (2006): The chemistry of conventional and alternative treatment systems for the neutralization of acid mine drainage. - Science of the Total Environment 366: 395-408.

[37] Kiran, B., Thanasekaran, K. (2011): Copper biosorption on Lyngbya putealis: application of response surface methodology (RSM). - International Biodeterioration and Biodegradation 65: 840-845.

[38] Kiran, M. G., Pakshirajan, K., Das, G. (2017): Heavy metal removal from multicomponent system by sulfate reducing bacteria: mechanism and cell surface characterization. - Journal of Hazardous Materials 324: 62-70.

[39] Koptsik, G. N., Koptsik, S. V., Smirnova, I. E. (2014): Efficiency of remediation of technogenic barrens around the Pechenganikel works in the Kola subarctic. - European Journal of Soil Science 47: 519-528.

[40] Koschorreck, M. (2008): Microbial sulphate reduction at a low pH. - FEMS Microbiology Ecology 64: 329-342. 
[41] Koschorreck, M., Frommichen, R., Herzsprung, P., Tittel, J., Wendt-Potthoff, K. (2002): Function of straw for in situ remediation of acidic mining lakes. - Water, Air and Soil Pollution 2: 97-109.

[42] Kumar, D., Gaur, J. P. (2011): Metal biosorption by two cyanobacterial mats in relation to $\mathrm{pH}$, biomass concentration, pre-treatment and reuse. - Bioresource Technology 102: 2529-2535.

[43] Malik, A. (2004): Metal bioremediation through growing cells. - Environment International 30: 261-278.

[44] Massocato, T. F., Ramos, J. C., Bascuñan, V. L. F., Simioni, C., Röriga, L. R., Bonomi, B. J. (2018): Tolerance of Ulothrix sp. LAFIC 010 (Chlorophyta) against high concentration of metals from acid mine drainage. - Ecotoxicology and Environmental Safety 157: 227-234.

[45] Matsunaga, T., Takeyama, H., Nakao, T., Yamazawa, A. (1999): Screening of marine microalgae for bioremediation of cadmium polluted seawater. - Journal of Biotechnology 70: 33-38.

[46] McKnight, D. M., Morel, F. M. M. (1980): Copper complexation by siderophores from filamentous blue-green algae. - Limnology and Oceanography 25: 62-71.

[47] Mehrabadi, A., Craggs, R., Farid, M. M. (2015): Wastewater treatment high rate algal ponds (WWT HRAP) for low-cost biofuel production. - Bioresource Technology 184: 202-214.

[48] Mehta, S. K., Gaur, J. P. (2005): Use of algae for removing heavy metal ions from wastewater: progress and prospects. - Critical Reviews in Biotechnology 25: 113-152.

[49] Molwantwa, J. B., Molipane, N. P., Rose, P. D. (2000): Biological sulphate reduction utilizing algal extracellular products as a carbon source. - WISA 2000 Biennial Conference, Sun City, South Africa.

[50] Nishikawa, K., Yamakoshi, Y., Uemura, I., Tominaga, N. (2003): Ultrastructural changes in Chlamydomonas acidophila (Chlorophyta) induced by heavy metals and polyphosphate metabolism. - FEMS Microbiology Ecology 44: 253-259.

[51] Novis, P. M., Harding, J. S. (2007): Extreme Acidophiles: Freshwater Algae Associated with Acid Mine Drainage. - In: Seckbach, J. (Ed.), Algae and Cyanobacteria in Extreme Environment. Springer, Dordrecht, pp. 443-463.

[52] Nowack, E., Schulin, R., Robinson, B. H. (2006): Critical assessment of chelantenhanced metal phytoextraction. - Environmental Science and Technology 40: 52255232 .

[53] Nriagu, J. O., Pacyna, J. M. (1988): Quantitative assessment of worldwide contamination of air, water and soils by trace metals. - Nature 333: 134-139.

[54] Nuhoglu, Y., Malkoc, E., Gürses, A., Canpolat, N. (2002): The removal of Cu (II) from aqueous solutions by Ulothrix zonata. - Bioresource Technology 85: 331-333.

[55] Oberholster, P. J., Genthe, B., Cheng, P., Botha, A-M. (2014): The potential of selected macroalgal species for treatment of AMD at different $\mathrm{pH}$ ranges in temperate regions. Water Resources 60: 82-92.

[56] Oberholster, P. J., Cheng, P., Botha, A-M., Philip, H., Liesl, H. (2018): Assessment of selected macroalgae for use in a biological hybrid system for treating sulphur in acid mine drainage (AMD). - Journal of Applied Phycology 30: 1361-1370.

[57] Orandi, S., Yaghubpur, A., Sahraei, H. (2007): Influence of AMD on aquatic life at Sar Cheshmeh copper mine. Abstract. - Goldschmidt Conference, Cologne, Germany.

[58] Oswald, W. J. (1988): Micro-algae and Waste-Water Treatment. - In: Borowitzka, M. A., Borowitzka, L. J. (eds.) Micro-algal Biotechnology. Cambridge University Press, Cambridge, pp. 305-328.

[59] Park, Y. T., Lee, H., Yun, H., Song, K., Yeom, S., Choi, J. (2013): Removal of metal from acid mine drainage using a hybrid system, including a pipes inserted microalgae reactor. -Bioresource Technology 150: 242-248. 
[60] Pavasant, P., Apiratikul, R., Sungkhum, V., Suthiparinyanont, P., Wattanachira, S., Marhaba, T. F. (2006): Biosorption of $\mathrm{Cu}^{2+}, \mathrm{Cd}^{2+}, \mathrm{Pb}^{2+}$, and $\mathrm{Zn}^{2+}$ using dried marine green macroalga Caulerpa lentillifera. - Bioresource Technology 97: 2321-2329.

[61] Pawlik-Skowrońska, B. (2001): Phytochelatin production in freshwater algae Stigeoclonium in response to heavy metals contained in mining water: effects of some environmental factors. - Aquatic Toxicology 52: 241-249.

[62] Payne, R. A., Van Hille, R. P., Duncan, J. R. (1999): The effect of toxic heavy metals on the alga Spirulina sp. - Proceedings of the Biannual Conference of the Water Institute of South Africa, Cape Town, South Africa.

[63] Perales-Vela, H. V., Peña-Castro, J. M., Cañizares-Villanueva, R. O. (2006): Heavy metal detoxification in eukaryotic microalgae. - Chemosphere 64: 1-10.

[64] Phillips, P., Bender, J., Simms, R., Rodriguez-Eaton, S., Britt, C. (1995): Manganese removal from acid coal-mine drainage by a pond containing green algae and microbial mat. - Water Science and Technology 31: 161-170.

[65] Prasad, M. N. V., Freitas, H. M. O. (2003): Metal hyperaccumulation in plants biodiversity prospecting for phytoremediation technology. - Electronic Journal of Biotechnology 6: 285-321.

[66] Priya, M., Gurung, N., Mukherjee, K., Bose, S. (2014): Microalgae in removal of heavy metal and organic pollutants from soil. - Microbial Biodegradation and Bioremediation. https://doi.org/10.1016/B978-0-12-800021-2.00023-6.

[67] Rao, P. H., Kumar, R. R., Raghavan, B. G., Subramanian, V. V., Sivasubramanian, V. (2011): Application of phycoremediation technology in the treatment of wastewater from a leather processing chemical manufacturing facility. - Water SA 37: 7-14.

[68] Robinson, J. D. F., Robb, G. A. (1995): Methods for the control and treatment of acid mine drainage. - Coal International 152-156.

[69] Rose, P. D., Boshoff, G. A., Van Hille, R. P., Wallace, L. C. M., Dunn, K. M., Duncan, J. R. (1998): An integrated algal sulphate reducing high rate ponding process for the treatment of acid mine drainage wastewaters. - Biodegradation 9: 247-257.

[70] Sharma, G. K., Khan, S. A. (2013): Bioremediation of sewage wastewater using selective algae for manure production. - International Journal of Environmental Engineering and Management 4: 573-580.

[71] Sheoran, A. S., Bhandari, S. (2005): Treatment of mine water by a microbial mat: bench scale experiments. - Mine Water and the Environment 24: 38-42.

[72] Sheoran, A. S., Sheoran, V., Choudhary, R. P. (2010): Bioremediation of acid-rock drainage by sulphate-reducing prokaryotes: a review. - Minerals Engineering 23: 10731100 .

[73] Shiraiwa, Y., Goyal, A., Tolbert, N. E. (1993): Alkalization of the medium by unicellular green algae during uptake of dissolved inorganic carbon. - Plant Cell Physiology 34: 649657.

[74] Stevens, A. E., McCarthy, B. C., Vis, M. L. (2001): Metal content of Klebsormidiumdominated (Chlorophyta) algal mats from acid mine drainage waters in south-eastern Ohio. -Journal of the Torrey Botanical Society 226-233.

[75] Toumi, A., Nejmeddine, A., El-Hamouri, B. (2000): Heavy metal removal in waste stabilisation ponds and high rate ponds. - Water, Science and Technology 42: 17-21.

[76] Travieso, L., Cañizares, R. O., Borja, R., Benitez, F., Domínguez, A. R., Dupeyrón, R., Valiente, V. (1999): Heavy metal removal by microalgae. - Bulletin of Environment Contamination and Toxicology 62: 144-151.

[77] Van Hille, R. P., Boshoff, G. A., Rose, P. D., Duncan, J. R. (1999): A continuous process for the biological treatment of heavy metal contaminated acid mine water. - Resources, Conservation and Recycling 27: 157-167.

[78] Vijayaraghavan, K., Prabu, D. (2006): Potential of Sargassum wightii biomass for copper (II) removal from aqueous solutions: application of different mathematical models to batch and continuous biosorption data. - Journal of Hazardous Materials 137: 558-564. 
[79] Vymazal, J. (1984): Short term uptake of heavy metals by periphyton algae. Hydrobiologia 119: 171-179.

[80] Wallace, L. C. M., van Hille, R. P., Boshoff, G. A., Rose, P. D., Duncan, J. R. (1997): Bioremediation of acidic mine effluent by an algal based system. - Proceedings Biotechnology SA, Grahamstown.

[81] Wang, J., Chen, C. (2009): Biosorbents for heavy metals removal and their future. Biotechnology Advances 27: 195-226.

[82] Wang, Y., Ho, S. H., Cheng, C. L., Guo, W. Q., Nagarajan, D., Ren, N. Q., Lee, D. J., Chang, J. S. (2016): Perspectives on the feasibility of using microalgae for industrial wastewater treatment. - Bioresource Technology 222: 485-497.

[83] White, C., Sayer, J. A., Gadd, G. M. (1997): Microbial solubilization and immobilization of toxic metals: key biogeochemical processes for treatment of contamination. - FEMS Microbiology Reviews 20: 503-516.

[84] Zagury, G. J., Neculita, C., Bussière, B. (2007): Passive treatment of acid mine drainage in bioreactors: short review, applications and research needs. - OttawaGeo 2007: 14391446.

[85] Zhang, M., Xingyu, L., Yibin, L., Guangyuan, W., Zining, W., Jiankang, W. (2017): Microbial community and metabolic pathway succession driven by changed nutrient inputs in tailings: effects of different nutrients on tailing remediation. - Scientific Reports 7(1): $1-10$. 